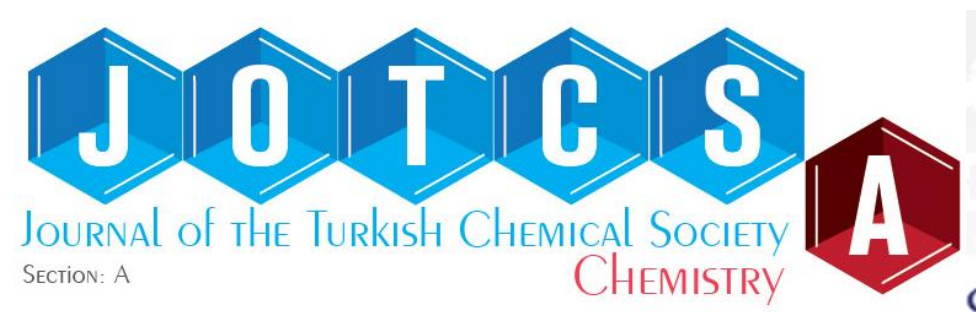

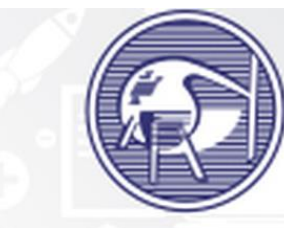

TURKISH

CHEMICAL SOCIETY

\title{
Evaluation of Total Polyphenol Content, Antioxidant Activity and Chemical Composition of Methanolic Extract from Allium Kharputense Freyn et. Sint. and Determination of Mineral and Trace Elements
}

\author{
Erdal YABALAK* ${ }^{(\mathbb{D})}$, A. Murat GizíR \\ Mersin University, Faculty of Arts and Science, Department of Chemistry, Mersin TR- \\ 33343 , Turkey
}

\begin{abstract}
Allium kharputense Freyn Et. Sint. (A. kharputense) was extensively investigated for analyzing total polyphenol content, antioxidant activity, chemical composition and mineral and trace element composition. Total polyphenolic content was determined as $257 \mathrm{mg} \mathrm{GA} 100 \mathrm{~g}^{-1}$ dried weight by using Folin-Ciocalteu method. DPPH test was performed for antioxidant activity analysis. IC ${ }_{50}$ values of gallic acid and Trolox were determined as $0.02642 \mathrm{mg} \mathrm{mL}^{-1}$ and $0.225 \mathrm{mg} \mathrm{mL}^{-1}$, respectively. $\mathrm{IC}_{50}$ value of $A$. kharputense was found as $2.186 \mathrm{mg} \mathrm{mL}^{-1}$. DPPH free radicalscavenging activity of extract from $1 \mathrm{mg}$ of $A$. kharputense was determined as $0.01207 \mathrm{mg} \mathrm{GAE}$ and $0.1029 \mathrm{mg}$ TrE, respectively. Chemical composition was determined using GC-MS. 28 compounds were detected in methanolic extracts of $A$. kharputense and these compounds were evaluated based on their medicinal and pharmaceutical effects. 20 minerals and trace elements were determined along with their levels by ICP-MS using microwave digestion procedure for preparing acid extracts.
\end{abstract}

Keywords: Antioxidant activity; allium kharputense Freyn Et. Sint; Polyphenolic content; DPPH; Chemical composition.

Submitted: May 22, 2017 . Revised: June 16, 2017. Accepted: June 30, 2017.

Cite this: Yabalak E, Gizir A. Evaluation of Total Polyphenol Content, Antioxidant Activity and Chemical Composition of Methanolic Extract from Allium Kharputense Freyn et. Sint. and Determination of Mineral and Trace Elements. JOTCSA. 2017 Jun;4(3):691-708.

DOI: $10.18596 /$ jotcsa. 315094.

*Corresponding author. e-mail: yabalakerdal@gmail.com. 


\section{INTRODUCTION}

A. kharputense which is regionally called "Soryaz" is one of the 179 species of Allium genus that grows up in Turkey (1). These species have been used worldwide for their economical, nutritional and traditional medicinal benefits for centuries (2-4). Several researchers have investigated Allium species for their pharmacological and therapeutic effects including chemopreventive and antitumor activity (5), antibacterial and antimicrobial (6,7), antifungal (8), anticoagulant, antihypertensive and anticancer $(9,10)$ activity. In addition, mutagenic and antimicrobial effect of methanolic extract from $A$. kharputense have been determined in our previous work (11).

Free radicals that formed during metabolic activities may cause cell ageing, cancer, mutagenic changes and cardiovascular diseases (12). These health risks can be prevented through consuming natural foods containing functional ingredients that exhibit antioxidative properties. Antioxidant compounds protect the organism against the damage caused by free radicals whom generation based on reactive oxygen species (13). Also, polyphenols are known as powerful antioxidants. Thus, evaluation of antioxidants activity, total polyphenol content, and identifying of chemical compounds of herbs gain great importance. Although, antioxidative properties of each compounds or polyphenols may vary from each other, it is more expressive to evaluate total antioxidant power and total polyphenol content due to the difficulty in the individually separation and quantification process. In addition, cooperative action of the antioxidants may enhance the benefits for health, too (13).

2,2-diphenyl-1-picrylhydrazyl (DPPH), which is soluble in methanol or ethanol is a highly stable and dark colored reagent employed in DPPH test (14). Being colored, DPPH has an absorption maximum at $515 \mathrm{~nm}$, but this absorption came to an end after discoloration of DPPH when reacts with an oxidant (15). DPPH test is an applicable and a fast method that is used for investigation of total antioxidant scavenging activity (16). Folin-Ciocalteu test is widely admitted method for measuring total phenolic content of food and herbs extracts $(17,18)$. Also, this reagent has a characteristic blue color at $700 \mathrm{~nm}$ when react with phenolic content of related matrix $(15,19)$. To the best of our knowledge, $A$. kharputense had never been investigated for its total polyphenol content, antioxidant activities and chemical composition. In the present study, these properties were investigated for methanolic 
extract from $A$. kharputense. Hence, two well-known methods such as DPPH free radical-scavenging activity (13) and Folin-Ciocalteu (19) methods were performed with some modifications for evaluation of antioxidant activity and total phenolic content, respectively.

Mineral and trace element composition of $A$. kharputense is another point of investigation that is firstly accomplished within this work. Mineral and trace elements composition of herbs has been drawn attention due to their medicinal effects and nutritional benefits (20). Although biogeochemical environment is the major source of the elements present in herbs, atmospheric dusts, fertilizers, pesticides, industrial and automobile exhaust constitute other factors that are effecting the levels of the elements $(21,22)$. Furthermore, determination of elemental content of herbs is necessary due to playing vital role in the formation of bio-active components and owing significant importance for metabolic process, such as human growth and general health of the human (22). Deficiency or excrescence of mineral and trace elements are essential in various process that may have both beneficial and adverse effect on human health (23). Thus, the levels of 20 elements that exist in $A$. kharputense ( $\mathrm{B}, \mathrm{Na}, \mathrm{Mg}, \mathrm{P}, \mathrm{K}, \mathrm{Ca}, \mathrm{Co}, \mathrm{Ni}, \mathrm{Cu}, \mathrm{Zn}, \mathrm{Se}, \mathrm{Cd}, \mathrm{Sn}, \mathrm{Ba}, \mathrm{Pb}, \mathrm{Cr}, \mathrm{Mn}, \mathrm{Fe}$ ) were enlightened owing to this work.

\section{MATERIALS AND METHODS}

\section{Materials}

Folin-Ciocalteu's phenol reagent, $\mathrm{HCl}, \mathrm{HNO}_{3}$ and $\mathrm{H}_{2} \mathrm{O}_{2}$ were supplied from Merck (Darmstadt, Germany), 3,4,5-trihydroxybenzoic acid (Gallic acid, GA), 6-hydroxy2,5,7,8-tetramethylchroman-2-carboxylic acid (Trolox, abbreviated as Tr), DPPH and C7-C40 saturated alkane mixture were obtained from Sigma-Aldrich (St. Louis, MO), anhydrous sodium carbonate was obtained from Fluka (USA). Helium and argon gases were supplied by Linde gas (Turkey). $0.45 \mu \mathrm{L}$ syringe filter was supplied from Agilent (Wilmington, DE, USA). Aqueous solutions were prepared using ultra-pure water supplied by Millipore Milli-Q Advantage A10.

\section{Instruments}

Soxhlet apparatus, Heidolph Hei-VAP rotary evaporator, Shimadzu UV-1601 spectrophotometer, GC-MS (GC: Agilent 7890A, MS: 5975C), Agilent 7500ce ICP-MS 
equipped with octopole reaction system (Japan), CEM MARS 250/40 microwave system (CEM Corporation, Matthews, NC).

\section{Plant material}

A. kharputense were collected and diagnosed as pointed out in our previous work (11). The specimens are deposited with deposit number of 7510 in the research herbarium of biology department of Mersin university, Turkey.

\section{Sample preparation and extraction}

Collected $A$. kharputense were air-dried in room conditions in dark for approximately 1 month and were crushed in a mill. $10 \mathrm{~g}$ of crushed and homogenized specimens were extracted with $350 \mathrm{~mL}$ of methanol using soxhlet extraction method for $4 \mathrm{~h}$. The obtained extracts were concentrated to $50 \mathrm{~mL}$ at $40{ }^{\circ} \mathrm{C}$ using rotary evaporator.

\section{Total phenol content analysis}

Total phenolic content in methanolic extract of $A$. kharputense were determined by using Folin-Ciocalteu's method according to Obanda et al. (19) with slight modification as follow. Briefly, $1 \mathrm{~mL}$ of concentrated extract solution and $1 \mathrm{~mL}$ of Folin-Ciocalteu's phenol reagent were mixed in a test tube. After 5 minutes, in which of the mixture was allowed to stand into dark, $2 \mathrm{~mL}$ of aqueous $\mathrm{Na}_{2} \mathrm{CO}_{3}$ solution (200 $\mathrm{g}$ of solid $\mathrm{Na}_{2} \mathrm{CO}_{3}$ dissolved in 1 liter of distilled water) were added on the mixture. Then, mixture was shaken thoroughly and final volume of the mixture was completed to $6 \mathrm{~mL}$ by adding $2 \mathrm{~mL}$ of ultrapure water. Blue color of the mixture was measured at $700 \mathrm{~nm}$ using UV spectrophotometer after $30 \mathrm{~min}$ of keeping the mixture in dark for completion of the reaction. Results were expressed as milligram of gallic acid equivalents ( $\mathrm{mg} \mathrm{GAE} / 100 \mathrm{~g} \mathrm{dw}$ ) by converting UV absorbances of samples into concentrations using a standard curve $\left(r^{2}=0,997\right)$ based on analyzing GA stock solutions (25-400 ppm) in same way mentioned above for samples.

\section{Antioxidant activity analysis by DPPH}

Antioxidant activity analysis of methanolic extract of $A$. kharputense was performed via free radical-scavenging activity of the extracts against DPPH according to modified method by Dziri et al. with slight modifications (13). $1 \mathrm{~mL}$ of every methanolic samples containing different amounts of extract $(0.5$ to $12 \mathrm{mg} A$. kharputense/mL of solution) were mixed with $2 \mathrm{~mL}$ of stock DPPH solution $\left(10^{-3} \mathrm{M}\right)$. 
UV absorbance was read at $515 \mathrm{~nm}$ for each sample after 15 minutes of standing at room temperature in dark. The absorbance of blank sample which was obtained through same way as sample's except containing extract but $1 \mathrm{~mL}$ of methanol instead, was excluded from the absorbance of related samples. The percentages of scavenging activity $(I)$ were calculated as reduce in absorbance of the samples $\left(A_{s}\right)$ versus DPPH stock solution $\left(A_{0}\right)$, as shown in Equation 1.

$$
I=\left[\left(A_{0}-A_{3}\right) / A_{b}\right] * 100
$$

IC 50 value, which represent the potential concentration of antioxidant to decrease the absorbance of stock DPPH solution by $50 \%$, was obtained as mg extract of $A$. kharputense per $\mathrm{mL}$ of solution using the graph (Figure 1) of the inhibition percentages against the extract concentration. In addition, IC 50 value of the extract was expressed as mg of GAE (Figure 2) and TrE (Figure 3), respectively, per $1 \mathrm{~mL}$ of solution employing inhibition graphs containing curves of both GA and $\operatorname{Tr}$ solutions against stock DPPH solution.

\section{Chemical composition analysis}

Gas chromatography equipped with mass spectrometry detector (scanning range: $\mathrm{M}^{+}=50-550 \mathrm{~m} / \mathrm{z}$ ) was used to determine compounds present in the extract. Concentrated extract samples were filtered through $0.45 \mu \mathrm{L}$ syringe filter and $1 \mu \mathrm{L}$ of filtered extract injected to GC-MS injection port $\left(250^{\circ} \mathrm{C}\right)$ in splitless mode. HP5-MS $(30 \mathrm{~m} \times 0.25 \mathrm{~mm} \times 0.25 \mu \mathrm{m})$ capillary column was used for separation. Helium was used as carrier gas at flow rate of $1.75 \mathrm{~mL} \mathrm{~min}^{-1}$ under fixed pressure of 21.21 psi. Analysis was carried out according to following temperature program:

Initial temperature of the oven was keep at $50^{\circ} \mathrm{C}$ for 2 min then increased to $100^{\circ} \mathrm{C}$ at $5{ }^{\circ} \mathrm{C} \mathrm{min}-1$ and held for $5 \mathrm{~min}$. Then, $150{ }^{\circ} \mathrm{C}$ at $5^{\circ} \mathrm{C} \mathrm{min}^{-1}$ and held for $10 \mathrm{~min}$. Finally, increased to $250{ }^{\circ} \mathrm{C}$ at $5{ }^{\circ} \mathrm{C} \mathrm{min}-1$ and held for $15 \mathrm{~min}$. In total, $72 \mathrm{~min}$ of analysis time was applied. C7 - C40 Saturated Alkane Mixture was used as certified reference material (1000 $\mathrm{gg} \mathrm{mL}^{-1}$ each component in hexane) to determine Kovats index of each compounds. 


\section{Determination of mineral and trace element composition}

Microwave system were used for acid digestion of dried $A$. kharputense samples via following operating parameters. $12 \mathrm{~mL}$ of $\mathrm{HNO}_{3}-\mathrm{HCl}$ digestion mixture, $\mathrm{H}_{2} \mathrm{O}_{2}$ and 0.5 $\mathrm{g}$ of dried samples were placed into microwave vessels. Then, the vessels were closed and let for digestion for 20 minutes at $200{ }^{\circ} \mathrm{C}$ in microwave oven. Finally, obtained acid extracts were diluted to $50 \mathrm{~mL}$ by ultrapure water. Detection of metal content was performed using ICP-MS instrument operated under following conditions: $1500 \mathrm{~W}$ of RF power, $15 \mathrm{~L} \mathrm{~min}^{-1}$ of plasma gas flow rate, $1 \mathrm{~L} \mathrm{~min}^{-1}$ of auxiliary gas flow rate, $1 \mathrm{~L} \mathrm{~min}^{-1}$ of carrier gas flow rate, $0.1 \mathrm{rps}$ of nebulizer pump, temperature of spray chamber of $2{ }^{\circ} \mathrm{C}, 8.6 \mathrm{~mm}$ of sample depth, $1 \mathrm{~mL} \mathrm{~min}{ }^{-1}$ of sample introduction flow rate. The external calibration method was used for all determinations using $\mathrm{Li}, \mathrm{Sc}, \mathrm{Ge}, \mathrm{Y}, \mathrm{In}, \mathrm{Tb}$ and $\mathrm{Bi}$ internal standard mixture which prepared in $2 \% \mathrm{HNO}_{3}$ matrix. Ten-point calibration curves were employed using NIST single element reference standards $\left(R^{2} \geq 0.999\right)$.

\section{RESULTS AND DISCUSSION}

\section{Method of extraction}

In general, the method of extraction has major effects on the composition of the extract. Thus, antioxidant potential and total phenolic content have been investigated by researchers using soxhlet extraction method $(13,24)$. In addition, solvent is another important parameter in the extraction process. For instance, methanol increases the efficiency of extraction of the polyphenolic compounds and it can easily be vaporized when comparing to water (25). Therefore, soxhlet extraction method was performed using methanol in the extraction process due to being reliable and efficient method.

\section{Total phenol content analysis}

The result of total polyphenol content analysis obtained as $257 \mathrm{mg} \mathrm{GAE} / 100 \mathrm{~g}$ on dried weight basis. Kaur and Kapoor (26) investigated some vegetables containing some most common Allium species such as Allium sativum and Allium cepa to determine their antioxidative and total phenolic properties. They determined total phenolic content of the vegetables in the range of $34-400 \mathrm{mg}$ of catechol/100 $\mathrm{g}$ on fresh weight basis and classified all vegetables in three group according to level of total phenolic content such as low, medium and high. When taking this classification 
into consideration, it can be said that $A$. kharputense show considerably high total phenolic content. In addition, Grace et al. determined total phenolic content of two wild Alaskan Vaccinium berries in range of 350-624 mg GAE/100 $\mathrm{g}$ on the fresh weight basis (27). Karabegović et al. used different extraction method concluding soxhlet method for analyzing polyphenol content, antioxidant and antimicrobial activities of the extracts obtained from dry aerial parts of two Artemisia species. They were found total phenolic compound as 123.4 and $128.1 \mathrm{mg}$ GAE/100 $\mathrm{g}$ on dried weight basis for each specie, respectively (24). Our results based on dried weight, so value of $257 \mathrm{mg}$ GAE seems to be significantly high.

\section{Antioxidant activity analysis}

The popularity of DPPH assay has been increasing among researchers due to being practicable, rapid and susceptible method for measuring free radical scavenging activity (4, 28, and 29). DPPH free radical scavenging analysis was performed to evaluate the radical scavenging of methanolic extract of $A$. kharputense. DPPH free radical scavenging activity percentages, in other words inhibition rates were given in percentages against concentration of extracts as shown in Figure 1. The IC50 value was found to be $2.186 \mathrm{mg} \mathrm{mL}^{-1}$ for extract from $A$. Kharputense according to Figure 1.

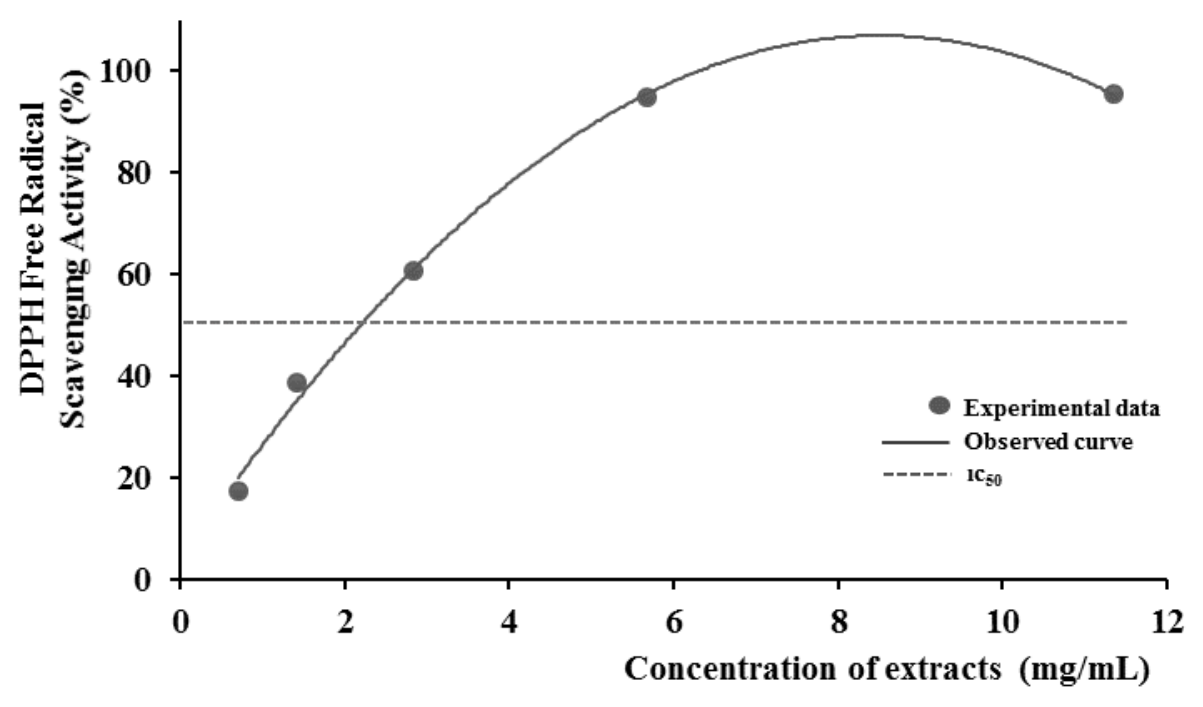

Figure 1: DPPH free radical scavenging activity rates of methanolic extract of $A$. kharputense. 
GA and Tr, which are widely known for their strong ability to scavenge free radical due to show high antioxidative capacity (30) were used as a standard to assess the free radical scavenging activity of extract. Also, IC $_{50}$ value of extracts were given on the basis of GA and Tr, taking advantages of Figure 2 and Figure 3. It is clearly shown from Figure 2 and Figure 3 that inhibition rate percentages increase with the concentration of GA and $\mathrm{Tr}$, respectively. Figure 2 and Figure 3 showed that $\mathrm{IC}_{50}$ values of $\mathrm{GA}$ and $\operatorname{Tr}$ were determined as $0.02642 \mathrm{mg} \mathrm{mL}^{-1}$ and $0.225 \mathrm{mg} \mathrm{mL}^{-1}$, respectively. Therefore, the free radical scavenging activity of extract from $A$. kharputense was found as $0.01207 \mathrm{mg} \mathrm{GAE}$ and $0.1029 \mathrm{mg} \mathrm{TrE}$, respectively.

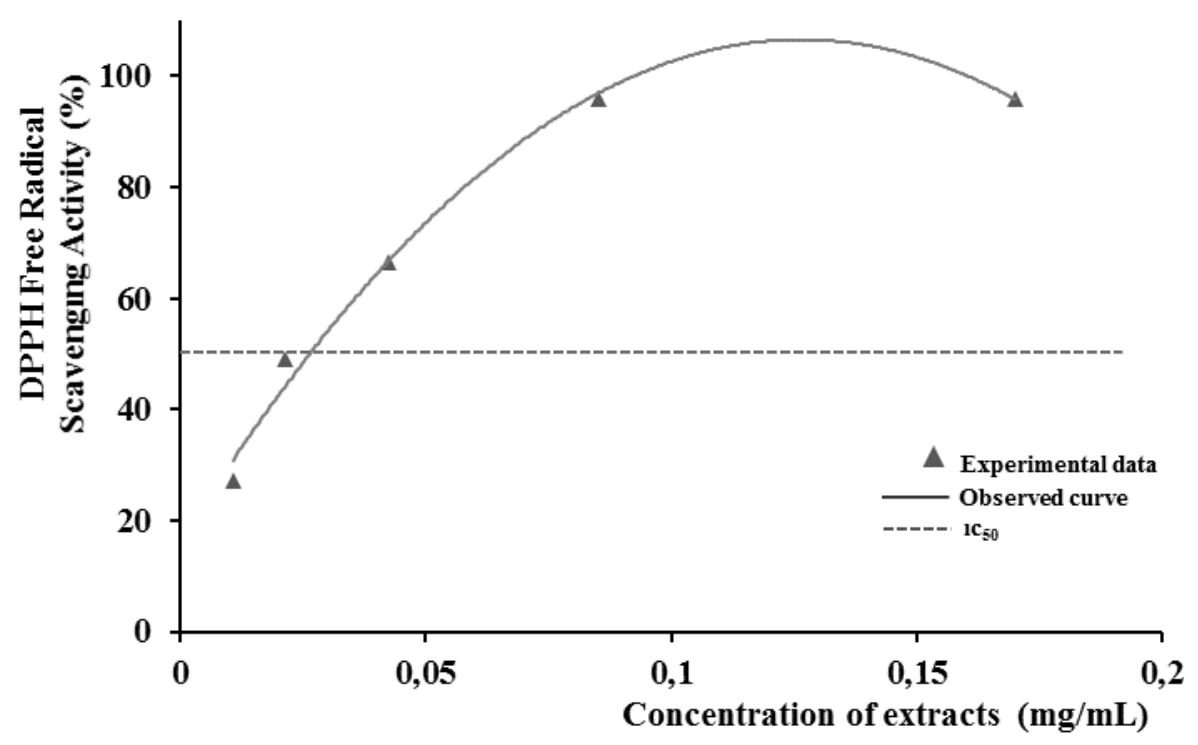

Figure 2: DPPH free radical scavenging activity rates of gallic acid. 


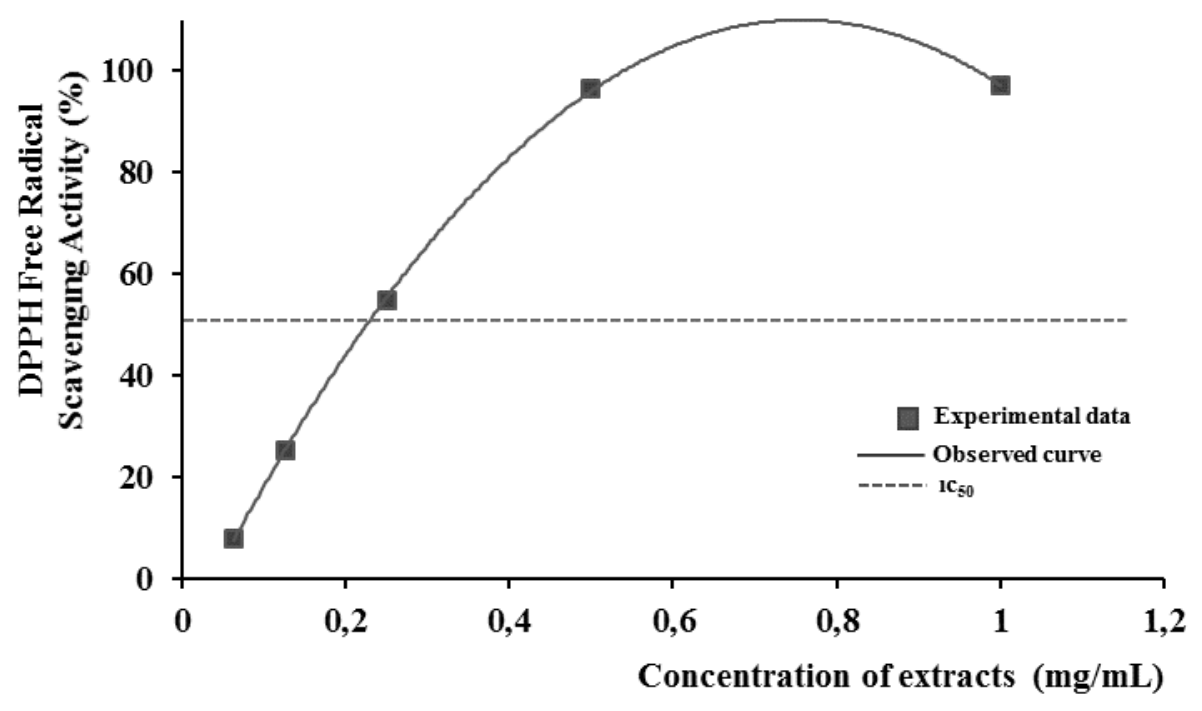

Figure 3: DPPH free radical scavenging activity rates of Trolox.

\section{Chemical composition analysis}

Chemical composition of methanolic extract from $A$. kharputense is displayed in Table 1. Compounds' names were given for all detected 28 components along with their retention times $\left(t_{r}\right)$, chemical formulas, molecular weights $\left(\mathrm{g} \mathrm{mol}^{-1}\right)$, peak quality (\%), and Kovats indices (KI). KI is the retention index that is used to standardize the retention times of separated and defined components obtained by employing gas chromatography system into system-independent constants by using a mixture of n-alkanes (31). Although parameters of chromatography system namely, column length and diameter, velocity, pressure and void time of carrier gas etc. effect the retention times, these parameters do not affect derived retention indices. In addition, retention index obtained from literature were given in the Table 1 for detected compounds.

Identification of all compounds given in Table 1 were made by computerized procedure based on matching mass spectrum of obtained compounds with those of Wiley7Nist05.L and NIST05a.L which are constitute mass spectral libraries of GC-MS system. Characteristics of identified compounds vary on wide range. In addition, these compounds establish the antioxidative activity and total phenolic potential of $A$. kharputense one by one or collectively. Thus, some of these compounds were evaluated and enlightened below, in the light of literature works. 
Mochizuki et al. indicated that Allium sativum L. have medicinal features such as antibacterial activity, antifungal activity, virucidal activity, etc. based on containing biologically active sulfur compounds (32). Herein, we obtained two sulfur compounds, namely dimethyl trisulfide and methyl (methylthio)methyl disulfide (component number of 1 and 4, respectively in Table 1 ) in this study.

2-Pyrrolidinone, with component number 3 in Table 1, was previously reported by Thangam et al. for its antioxidant activity and potential anticancer effects (33). Another compounds which was reported by Terpinc et al. that has antioxidative potential was 4-vinylphenol given in table 1 with component number 5 (34). 2Methoxy-4-vinylphenol, with component number 7 in Table 1, was reported by ShuFeng et al. They denoted that 2-methoxy-4-vinylphenol is one of the major compounds detected in essential oil which is extracted from Nandina domestica fruits and exhibited significant antioxidant activities (35).

Carabineiro et al. applied aromatization process to synthesize 2-phenylpyrrole (numbered as 12 in the Table 1). They referred to the importance of such heterocyclic organic compounds (such as polypyrroles) and their roles in the natural products, synthetic pharmaceutical, etc. (36). da Silva et al. detected 2,6-Dimethyl3-(methoxymethyl)-p-benzoquinone (numbered as 14 in the Table 1 ) in the GC-MS analysis of Bulbophyllum (Orchidaceae) which KI value is coherent with our findings (37).

Horton et al. pointed out that norharmane ( $\beta$-carboline) (numbered as 20 in the Table 1) showed significant antioxidant activity against peroxyl radical which is reported as one of the naturally occurred reactive oxygen species. They recommend norharmane for its potential role in the treatment of Alzheimer's disease (38).

Lalitharani et al. identified the components of ethanolic extract of Pothos scandens L. leaf using GC-MS. They revealed that palmitic acid (numbered as 18 in the Table 1) has antioxidant activity potential and Linoleic acid (numbered as 22 in the Table 1) has anti-inflammatory and antiarthritic properties where Linoleic acid ethyl ester (numbered as 21 in the Table 1) was detected in our study, too (39). Additionaly, Park et al. verified the anti-inflammatory activity of Linoleic acid ethyl ester extracted from Allium sativum (component number of 21 in Table 1) (40). 
$\mathrm{Y}$-Tocopherol and a-Tocopherol which are known as types of bio-active compounds, vitamin E (41-42), (numbered as 27 and 28, respectively in the Table 1) were reported as endogenous antioxidant by Rice-Evans et al. and they also mentioned that a-Tocopherol has properties as being chain-breaking lipid peroxyl radical scavenger (43). 
Table 1: Components detected by GC-MS obtained from methanolic extract of $A$. kharputense.

\begin{tabular}{|c|c|c|c|c|c|c|c|c|}
\hline $\begin{array}{l}\text { C. } \\
\text { NO }\end{array}$ & $\mathbf{t}_{\mathbf{r}}$ & Compound Name & $\begin{array}{l}\text { Chemical } \\
\text { Formula }\end{array}$ & $\begin{array}{l}\text { Molecular Weight } \\
\text { (g/mol) }\end{array}$ & $\begin{array}{l}\text { Quality } \\
(\%)\end{array}$ & $\mathbf{K I}$ & RIL & $\begin{array}{l}\text { Ref. } \\
\text { No }\end{array}$ \\
\hline 1 & 8.57 & Dimethyl trisulfide & $\mathrm{C}_{2} \mathrm{H}_{6} \mathrm{~S}_{3}$ & 126.26 & 94 & 975.64 & 972 & 44 \\
\hline 2 & 12.56 & {$[1,3]$ Diazepan-2,4-dione } & $\mathrm{C}_{5} \mathrm{H}_{8} \mathrm{~N}_{2} \mathrm{O}_{2}$ & 128.06 & 83 & 1084.27 & nd & nd \\
\hline 3 & 12.89 & 2-Pyrrolidinone & $\mathrm{C}_{4} \mathrm{H}_{7} \mathrm{NO}$ & 85.10 & 90 & 1092.39 & 1077 & 45 \\
\hline 4 & 13.38 & methyl (methylthio)methyl disulfide & $\mathrm{C}_{3} \mathrm{H}_{8} \mathrm{~S}_{4}$ & 140.30 & 74 & 1205.77 & nd & nd \\
\hline 5 & 18.54 & 4-vinylphenol & $\mathrm{C}_{8} \mathrm{H}_{8} \mathrm{O}$ & 120.15 & 80 & 1257.55 & 1229 & 46 \\
\hline 6 & 21.31 & $1 \mathrm{H}$-Indole & $\mathrm{C}_{8} \mathrm{H}_{7} \mathrm{~N}$ & 117.15 & 91 & 1323.27 & 1327 & 47 \\
\hline 7 & 22.04 & 2-Methoxy-4-vinylphenol & $\mathrm{C}_{9} \mathrm{H}_{10} \mathrm{O}_{2}$ & 150.17 & 96 & 1338.79 & 1330 & 48 \\
\hline 8 & 24.85 & L-Glutamic acid & $\mathrm{C}_{5} \mathrm{H}_{9} \mathrm{NO}_{4}$ & 147.13 & 72 & 1398.32 & nd & nd \\
\hline 9 & 25.12 & L-Proline & $\mathrm{C}_{5} \mathrm{H}_{9} \mathrm{NO}_{2}$ & 115.06 & 80 & 1405.33 & nd & nd \\
\hline 10 & 28.49 & 3-Methyl-thiophene-2-carboxamide & $\mathrm{C}_{6} \mathrm{H}_{7} \mathrm{NOS}$ & 141.19 & 72 & 1495.50 & nd & nd \\
\hline 11 & 28.72 & Diphenylamine & $\mathrm{C}_{12} \mathrm{H}_{11} \mathrm{~N}$ & 169.22 & 84 & 1501.74 & 1567 & 49 \\
\hline 12 & 30.33 & 2-Phenylpyrrole & $\mathrm{C}_{10} \mathrm{H}_{9} \mathrm{~N}$ & 143.19 & 93 & 1546.83 & nd & nd \\
\hline 13 & 31.08 & 2,5-Cyclohexadiene-1,4-dione & $\mathrm{C}_{6} \mathrm{H}_{4} \mathrm{O}_{2}$ & 108.09 & 86 & 1567.79 & nd & nd \\
\hline 14 & 31.13 & $\begin{array}{l}\text { 2,6-Dimethyl-3-(methoxymethyl)-p- } \\
\text { benzoquinone }\end{array}$ & $\mathrm{C}_{10} \mathrm{H}_{12} \mathrm{O}_{3}$ & 180.20 & 86 & 1569.10 & 1573 & 37 \\
\hline 15 & 31.76 & 1,2,3,4-Tetrahydro-cyclopenta[b]indole & $\mathrm{C}_{11} \mathrm{H}_{11} \mathrm{~N}$ & 157.21 & 87 & 1586.89 & nd & nd \\
\hline 16 & 40.97 & Thiazolo[3,2-a]pyridinium & $\mathrm{C}_{7} \mathrm{H}_{6} \mathrm{NS}^{+}$ & 136.19 & 70 & 1763.97 & nd & nd \\
\hline 17 & 47.03 & 2-Methyl-3-ethylthiopyrazine & $\mathrm{C}_{7} \mathrm{H}_{10} \mathrm{~N}_{2} \mathrm{~S}$ & 154.23 & 72 & 1954.52 & nd & nd \\
\hline 18 & 47.15 & palmitic acid & $\mathrm{C}_{16} \mathrm{H}_{32} \mathrm{O}_{2}$ & 256.42 & 98 & 1957.32 & 1957 & 50 \\
\hline 19 & 48.30 & 6-Butyl-2,2'-bipyridyl & $\mathrm{C}_{14} \mathrm{H}_{16} \mathrm{~N}_{2}$ & 212.29 & 90 & 1984.19 & nd & nd \\
\hline 20 & 48.79 & Norharmane & $\mathrm{C}_{11} \mathrm{H}_{8} \mathrm{~N}_{2}$ & 168.19 & 91 & 1995.63 & nd & nd \\
\hline 21 & 50.28 & Linoleic acid ethyl ester & $\mathrm{C}_{20} \mathrm{H}_{36} \mathrm{O}_{2}$ & 308.50 & 99 & 2112.22 & 2144 & 51 \\
\hline 22 & 51.41 & Linoleic acid & $\mathrm{C}_{18} \mathrm{H}_{32} \mathrm{O}_{2}$ & 280.45 & 99 & 2221.26 & 2179 & 52 \\
\hline 23 & 51.84 & 2-Hexadecen-1-ol & $\mathrm{C}_{16} \mathrm{H}_{32} \mathrm{O}$ & 240.42 & 76 & 2273.51 & nd & nd \\
\hline 24 & 53.09 & 9-Tricosene & $\mathrm{C}_{23} \mathrm{H}_{46}$ & 322.61 & 97 & 2312.38 & 2298 & 53 \\
\hline 25 & 56.93 & Z-12-Pentacosene & $\mathrm{C}_{25} \mathrm{H}_{50}$ & 350.66 & 99 & 2328.41 & nd & nd \\
\hline 26 & 62.30 & 1-Dotriacontanol & $\mathrm{C}_{32} \mathrm{H}_{66} \mathrm{O}$ & 466.87 & 87 & 2860.58 & nd & nd \\
\hline 27 & 69.43 & Y-Tocopherol & $\mathrm{C}_{28} \mathrm{H}_{48} \mathrm{O}_{2}$ & 416.68 & 93 & 3112.41 & 3074 & 54 \\
\hline 28 & 71.69 & a-Tocopherol & $\mathrm{C}_{29} \mathrm{H}_{50} \mathrm{O}_{2}$ & 430.71 & 99 & 3156.61 & 3149 & 54 \\
\hline
\end{tabular}

$\mathrm{t}_{\mathrm{r}}$ : Retention times, C. No: Component number, KI: Kovats index, RIL: Retention Index obtained from literature, nd: not detected 


\section{Determination of mineral and trace element composition}

Table 2: Total content of metals (ppm) in dried $A$. kharputense.

\begin{tabular}{|c|c|c|c|c|c|c|c|c|c|}
\hline B & $\mathrm{Na}$ & $\mathbf{M g}$ & $\mathbf{P}$ & K & $\mathrm{Ca}$ & Co & $\mathbf{N i}$ & $\mathrm{Cu}$ & As \\
\hline $\begin{array}{c}0.0017 \pm \\
0.0001 \\
\end{array}$ & $\begin{array}{c}108.0 \\
\pm 4.8 \\
\end{array}$ & $\begin{array}{c}1282.4 \\
\pm 8.6\end{array}$ & $\begin{array}{l}4071.0 \\
\pm 19.7 \\
\end{array}$ & $\begin{array}{c}4455.0 \\
\pm 12.3 \\
\end{array}$ & $\begin{array}{c}5419.7 \\
\pm 11.1 \\
\end{array}$ & $\begin{array}{l}1.4 \pm \\
0.08 \\
\end{array}$ & $\begin{array}{c}11.2 \pm \\
0.84 \\
\end{array}$ & $\begin{array}{c}19.1 \pm \\
0.65 \\
\end{array}$ & nd \\
\hline $\mathrm{Zn}$ & $\mathrm{Se}$ & Cd & Sn & $\mathrm{Ba}$ & $\mathbf{P b}$ & $\mathrm{Cr}$ & Mn & $\mathrm{Fe}$ & Al \\
\hline $\begin{array}{c}67.7 \pm 1.2 \\
1\end{array}$ & nd & nd & $\begin{array}{c}0.64 \pm 0 \\
.07\end{array}$ & $\begin{array}{c}5.4 \pm 0 . \\
71\end{array}$ & nd & nd & $\begin{array}{c}54.8 \pm \\
3.45\end{array}$ & $\begin{array}{l}703.6 \\
\pm 6.58\end{array}$ & $\begin{array}{l}474.2 \\
\pm 5.11\end{array}$ \\
\hline
\end{tabular}

nd: not dedected

Total content of metals in dried $A$. kharputense were demonstrated in ppm concentrations in Table 2. According to this table, the maximum concentration was found for $\mathrm{Ca}$ (5419.7 ppm) and the minimum concentration was found for B (0.0017 $\mathrm{ppm}$ ), where $\mathrm{Ar}$, Se, $\mathrm{Cd}, \mathrm{Pb}$ and $\mathrm{Cr}$ were remained under detection limits. As clearly shown from Table 1, trace elements which have reverse effect for human health or have toxic potential for plants and animals, especially in high levels, were not detected ( $\mathrm{As}, \mathrm{Cd}, \mathrm{Pb}$ and $\mathrm{Cr}$ ) or at least found in considerably low levels ( $\mathrm{Cu}, \mathrm{Co}$, and $\mathrm{Ni})$ (23). For instance, cadmium is known as carcinogenic for humans (55). Besides, phosphate based fertilizers is responsible of lots of trace metals including Cd (56). Thus, fertilizer applications must be controlled by authorities and fertilizers which are devoid of toxic heavy metals should be suggested. Nevertheless, nutritional trace elements such as $\mathrm{K}, \mathrm{Na}, \mathrm{Ca}, \mathrm{P}, \mathrm{Fe}, \mathrm{Mn}$ and $\mathrm{Zn}$ were found comparatively in high levels.

\section{CONCLUSION}

Belonging to Allium genus, $A$. kharputense is worth investigating due to the fact that Allium genus have been used as a food herb for centuries and it has medicinal and economical properties. Thus, comprehensive analysis including, total phenolic content, DPPH free radical scavenging activity, chemical composition and mineral and trace element composition were performed in this study. Considering obtained results, it can be said that, levels of total phenol content and antioxidant activity, based on DPPH radical scavenging activity, were found to be higher than lots of herbs reported by various researchers. In addition, on the basis of the importance of the chemical compounds in the pharmaceutical and medicinal process, chemical composition was determined and numerous obtained compounds were evaluated comparing literature work. It was demonstrated that $A$. kharputense is a substantial 
herb based on containing lots of valuable compounds in terms of medical and drug effect. Moreover, 20 elements and their concentrations were determined using ICPMS. Overall, A. kharputense should be evaluated for being potential source of microelements for human and its probable bio-chemical effects should be investigated in further studies.

\section{ACKNOWLEDGMENTS}

This study was supported by the Research Fund of Mersin University in Turkey with Project Number: 2017-1-AP1-2207

\section{REFERENCES}

1. Firat M. The Ethnobotanical Usage of Some East Anatolian. Manas J Agric Life Sci. 2015; 5(1): 80-6.

2. Block E. The Chemistry of Garlic and Onions. Sci Am. 1985; 252(3): 114-8.

3. Hanen N, Fattouch S, Ammar E, Neffati M. Antimicrobial potentials of Allium roseum: Recent Advances and Trends. Sci against Microb Pathog Commun Curr Res Technol Adv. $2011 ; 2(1): 1205-10$.

4. Demirtas I, Erenler R, Elmastas M, Goktasoglu A. Studies on the antioxidant potential of flavones of Allium vineale isolated from its water-soluble fraction. Food Chem. 2013; 136(1): 34-40.

5. Reuter HD. Allium sativum and Allium ursinum: Part 2 pharmacology and medicinal application. Phytomedicine. Gustav Fischer Verlag, Struttgart · Jena · New York; 1995; 2(1): 73-91.

6. Fritsch RM, Keusgen M. Occurrence and taxonomic significance of cysteine sulphoxides in the genus Allium L. (Alliaceae). Phytochemistry. 2006; 67(11): 1127-35.

7. Panomket $P$, Wanram S, Srivorasmas $T$, Pongprom N. Bioactivity of plant extracts against Burkholderia pseudomallei. Asian Biomed. 2012; 6(4):619-23.

8. Corea G, Fattorusso E, Lanzotti V. Saponins and flavonoids of Allium triquetrum. J Nat Prod. 2003; 66(11): 1405-11.

9. Kimbaris AC, Siatis NG, Daferera DJ, Tarantilis PA, Pappas CS, Polissiou MG. Comparison of distillation and ultrasound-assisted extraction methods for the isolation of sensitive aroma compounds from garlic (Allium sativum). Ultrason Sonochem. 2006; 13(1): 54-60.

10. Banerjee SK, Mukherjee PK, Maulik SK. Garlic as an antioxidant: The good, the bad and the ugly. Phyther Res. 2003; 17(2): 97-106.

11. Erdogan EA, Yabalak E, Everest A, Gizir AM. Mutagenic and antimicrobial evaluation of methanol extract from Allium kharputense Freyn Et. Sint. Spatula DD. 2015; 5(2): 83-7. 
12. Thaipong K, Boonprakob U, Crosby K, Cisneros-Zevallos L, Hawkins Byrne D. Comparison of ABTS, DPPH, FRAP, and ORAC assays for estimating antioxidant activity from guava fruit extracts. J Food Compos Anal. 2006; 19(6-7): 669-75.

13. Dziri S, Hassen I, Fatnassi S, Mrabet $Y$, Casabianca H, Hanchi B, et al. Phenolic constituents, antioxidant and antimicrobial activities of rosy garlic (Allium roseum var. odoratissimum). J Funct Foods. 2012; 4(2): 423-32.

14. Figueiredo C, Barroso J, Pedro L, Scheefeer J. Factors affecting secondary metabolite production in plants: volatile components and essential oils. Flavour Fragr J. 2007; 22(November): 206-13.

15. Amorati R, Valgimigli L. Advantages and limitations of common testing methods for antioxidants. Free Radic Res. 2015; 49(5): 633-49.

16. Wollinger A, Perrin E, Chahboun J, Jeannot V, Touraud D, Kunz W. Antioxidant activity of hydro distillation water residues from Rosmarinus officinalis L. leaves determined by DPPH assays. Comptes Rendus Chim. 2016; 19(6): 754-65.

17. Feng CY, Wang WW, Ye JF, Li SS, Wu Q, Yin DD, et al. Polyphenol profile and antioxidant activity of the fruit and leaf of Vaccinium glaucoalbum from the Tibetan Himalayas. Food Chem. 2017; 219: 490-5.

18. Thaipong K, Boonprakob U, Crosby K, Cisneros-Zevallos L, Hawkins Byrne D. Comparison of ABTS, DPPH, FRAP, and ORAC assays for estimating antioxidant activity from guava fruit extracts. J Food Compos Anal. 2006; 19(6-7): 669-75.

19. Obanda M, Owuor PO. Flavanol Composition and Caffeine Content of Green Leaf as Qualit y Potential Indicators of Kenyan Black Teas. J Sci Food Agric. 1997; 74: 209-215.

20. Tokalığlu Ş. Determination of trace elements in commonly consumed medicinal herbs by ICP-MS and multivariate analysis. Food Chem. 2012; 134(4): 2504-8.

21. Baye $\mathrm{H}$, Hymete $\mathrm{A}$. Lead and cadmium accumulation in medicinal plants collected from environmentally different sites. Bull Environ Contam Toxicol. 2010; 84(2): 197-201.

22. Pytlakowska K, Kita A, Janoska P, Połowniak M, Kozik V. Multi-element analysis of mineral and trace elements in medicinal herbs and their infusions. Food Chem. 2012; 135(2): 494-501.

23. Karak T, Bhagat RM. Trace elements in tea leaves, made tea and tea infusion: A review. Food Res Int. 2010; 43(9): 2234-52.

24. Karabegović I, Nikolova M, Veličković D, Stojičević S, Veljković V, Lazić M. Comparison of antioxidant and antimicrobial activities of methanolic extracts of the artemisia sp. recovered by different extraction techniques. Chinese J Chem Eng. 2011; 19(3): 504-11.

25. Lim YY, Quah EPL. Antioxidant properties of different cultivars of Portulaca oleracea. Food Chem. 2007; 103(3): 734-40.

26. Charanjit K, Harish CK, Anti-oxidant activity and total phenolic content of some Asian vegetables, International J Food Sci Technol. 2002; 3: 153-61.

27. Grace MH, Esposito D, Dunlap KL, Lila MA. Comparative Analysis of Phenolic Content and Pro fi le, Antioxidant Capacity, and Anti-in flammatory Bioactivity in Wild Alaskan and Commercial Vaccinium Berries. J Agric food Chem. 2014; 62(18): 4007-4017.

28. Özcelik B, Lee J, Min D. Effects of Light, Oxygen, and pH on the Absorbance of 2, 2Diphenyl-1-picrylhydrazyl. J Food Sci. 2003; 68(2): 487-90. 
29. Wang $Y$, Gao $Y$, Ding $H$, Liu S, Han X, Gui J, et al. Subcritical ethanol extraction of flavonoids from Moringa oleifera leaf and evaluation of antioxidant activity. Food Chem. 2017; 218: 152-8.

30. Apak R, Güçlü K, Demirata B, Özyürek M, Çelik SE, Bektaşoğlu B, et al. Comparative evaluation of various total antioxidant capacity assays applied to phenolic compounds with the CUPRAC assay. Molecules. 2007; 12(7): 1496-547.

31. Kovats E, Gas-chromatographische Charakterisierung organischer Verbindungen. Teil 1: Retentionsindices aliphatischer Halogenide, Alkohole, Aldehyde und Ketone. Helv Chim Acta. $1958 ;$ 41(7): 1915-32.

32. Mochizuki E, Yamamoto T, Komiyama Y, Nakazawa H. Identification of Allium Products Using Flame Photometric Detection Gas Chromatography and Distribution Patterns of Volatile Sulfur Compounds. J Agric Food Chem. 1998; 46(12): 5170-6

33. Thangam R, Suresh V, Rajkumar M, Vincent JD, Gunasekaran P, Anbazhagan C, et al. Antioxidant and in vitro anticancer effect of 2-pyrrolidinone rich fraction of Brassica oleracea var. capitata through induction of apoptosis in human cancer cells. Phytother Res. 2013; 27(11): 1664-70.

34. Terpinc $P$, Polak $T$, Šegatin N, Hanzlowsky A, Ulrih NP, Abramovič H. Antioxidant properties of 4-vinyl derivatives of hydroxycinnamic acids. Food Chem. 2011; 128(1): 629.

35. Bi S-F, Zhu G-Q, Wu J, Li Z-K, Lv Y-Z, Fang L. Chemical composition and antioxidant activities of the essential oil from Nandina domestica fruits. Nat Prod Res. 2016; 30(3): 362-5.

36. Carabineiro SA, Bellabarba RM, Gomes PT, Fonseca IM. Aromatisation of 2-phenyl-1pyrroline to 2-phenylpyrrole using activated carbon. Catal Letters. 2006; 111(3-4): 2215.

37. Da Silva UF, Borba EL, Semir J, Marsaioli AJ. A simple solid injection device for the analyses of Bulbophyllum (Orchidaceae) volatiles. Phytochemistry. 1999; 50(1): 31-4.

38. Horton W, Sood A, Peerannawar S, Kugyela N, Kulkarni A, Tulsan R, et al. Synthesis and application of ??-carbolines as novel multi-functional anti-Alzheimer's disease agents. Bioorganic Med Chem Lett. 2017; 27(2): 232-6.

39. Lalitharani S, Mohan VR, Regini GS, Kalidass C. GC-MS analysis of ethanolic extract of Pothos scandens leaf. J Herb Medi Toxicol. 2009; 3(2): 159-60.

40. Park SY, Seetharaman R, Ko MJ, Kim DY, Kim TH, Yoon MK, et al. Ethyl linoleate from garlic attenuates lipopolysaccharide-induced pro-inflammatory cytokine production by inducing heme oxygenase-1 in RAW264.7 cells. Int Immunopharmacol. 2014; 19(2): 253-61.

41. Jiang Q, Christen S, Shigenaga MK, Ames BN. gamma-Tocopherol, the major form of vitamin $E$ in the US diet, deserves more attention. Am J Clin Nutr. 2001; 74(6): 714-22.

42. Karl-Heinz W, Kamal-Eldin A, Elmadfa I. "Gamma-tocopherol-an underestimated vitamin?". Ann nutr metab. 2004; 48(3): 169-188

43. Rice-Evans CA, Miller NJ, Paganga G. Structure-antioxidant activity relationships of flavonoids and phenolic acids. Free Radic Biol Med. 1996; 20(7): 933-56. 
44. Jarunrattanasri A, Theerakulkait C, Cadwallader KR. Aroma Components of AcidHydrolyzed Vegetable Protein Made by Partial Hydrolysis of Rice Bran Protein. J Agric Food Chem. 2007; 55(8): 3044-3050

45. Kim $\mathrm{TH}_{L}$ Shin $\mathrm{J}_{L}$ Baek $\mathrm{HH}_{L}$ Lee $\mathrm{HJ}_{\underline{L}}$. Volatile flavour compounds in suspension culture of Agastache rugosa Kuntze (Korean mint), J Sci Food Agric. 2001; 81(6): 569-575.

46. Ansorena $\mathrm{D}_{\perp}$ Gimeno $\mathrm{O}_{\perp}$ Astiasarán $\mathrm{I}_{\perp}$ Bello $\mathrm{J}_{\underline{\alpha}}$ Analysis of volatile compounds by GC-MS of a dry fermented sausage: chorizo de Pamplona. Food Res Int. 2001; 34(1): 67-75.

47. Robledo $\mathrm{N}_{\perp}$ Arzuffi $\mathrm{R}_{\underline{.}}$ Identificacion de los compuestos volatiles de papaya y cuaguayote mediante microextraccion en fase solida, cromatografia de gases y espectrometria de masas. Rev Latinoamericana Quim. 2004; 32(1): 30-36.

48. Varlet $V_{\perp}$ Serot $T_{\perp}$ Cardinal $M_{\perp}$ Knockaert $C_{\perp}$ Prost $C$. Olfactometric Determination of the Most Potent Odor-Active Compounds in Salmon Muscle (Salmo salar) Smoked by Using Four Smoke Generation Techniques. J Agric Food Chem. 2007; 55(11): 4518-4525.

49. Alley $\mathrm{BJ}_{\perp}$ Dykes $\mathrm{HWH}_{ \pm}$Gas-Liquid Chromatographic Determination of Nitrate Esters, Stabilizers and Plasticizers in Nitrocellulose-Base Propellants. J Chromatogr. 1972; 71(1): 23-37.

50. Formisano $C_{L}$ Senatore $F_{L}$ Bruno $M_{L}$ Bellone $G$. Chemical composition and antimicrobial activity of the essential oil of Phlomis ferruginea Ten. (Lamiaceae) growing wild in Southern Italy. Flavour Fragr J. 2006; 21(5): 848-851.

51. Tzakou $\mathrm{O}_{\perp}$ Said $\mathrm{A}_{\perp}$ Farag $\mathrm{A}_{\perp}$ Rashed K. Volatile constituents of Ailanthus excelsa Roxb. Flavour Fragr J. 2006; 21(6): 899-901.

52. Sandoval-Montemayor $\mathrm{NE}_{\perp}$ Garcia $\mathrm{A}_{\perp}$ Elizondo-Trevino $\mathrm{E}_{\perp}$ Garza-Gonzales $\mathrm{E}_{\perp}$ Alvarez $\mathrm{L}_{\perp}$ Camacho-Corona MdelR. Chemical composition of hexane extract of Citrus aurantifolia and anti-mycobacterium tuberculosis activity of some of its constituents. Molecules. 2012; 17(12): 11173-11184.

53. Saroglou $V_{\perp}$ Dorizas $N_{\perp}$ Kypriotakis $Z_{\perp}$ Skaltsa HD. Analysis of the essential oil composition of eight Anthemis species from Greece. J Chromatogr A. 2006; 1104(1-2): 313-322.

54. Andriamaharavo NR. Retention Data. NIST Mass Spectrometry Data Center. 2014.

55. Michael P W. Cadmium carcinogenesis in review. J Inorg Biochem. 2000; 79(1-4): 241-4.

56. Cupit M, Larsson O, de Meeûs C, Eduljee GH, Hutton, M, Assessment and management of risks arising from exposure to cadmium in fertilizers-II. Sci Total Environ. 2002; 291; 189-206. 
